Katsaus

\title{
Pysähdyttävät paikat
}

\author{
Videoitu kävelyhaastattelu etnografisena menetelmänä
}

\author{
Karoliina Ojanen
}

$\mathrm{T}$

ässä katsauksessa pohdin videoidun kävelyhaastattelun menetelmällisiä mahdollisuuk-

sia etnografisen tiedon tuottamisessa. Tarkastelen sitä, miten paikkoihin liittyvät merkitykset rakentuvat videoidun kävelyhaastattelun vuorovaikutuksessa. Analyysi pohjautuu neljään kävelyhaastatteluun, joissa haastateltavien valitsemat reitit on kuvattu Gopro-kameralla. Haastattelijan ja haastateltavan puheen lisäksi analysoitavaksi asettuu myös reitti videolle tallentuneina kuvina ja maisemina. Uusmaterialistisen ajattelun mukaan maisemallakin on toimijuutensa, mutta en keskity analysoimaan maiseman toimijuutta, vaan pikemminkin videokuvan välittämän maiseman ja haastatteluun osallistuvien henkilöiden kautta rakentuvaa paikkakäsitystä haastattelutilanteessa. Analyysissa keskityn videokameraan yhtenä paikan merkityksiä rakentavana toimijana. Pohdin sitä, miten paikka merkityksellistyy toimijoiden, toisin sanoen haastateltavan, haastattelijan ja videokuvan, vuorovaikutuksessa, ja millaisia mahdollisuuksia videoitu kävelyhaastattelu menetelmänä tuo etnografiseen tiedon tuottamiseen.

Tutkimushankkeessamme Jaettu kaupunki. Kaupunki kosmopoliittisena suojana (2017-2018, Kaupunkitutkimus ja metropolipolitiikka -tutkimus ja yhteistyöohjelma) olemme kiinnostuneita paikkoihin liittyvistä merkityksistä ja eritaustaisten inmisten paikkakokemuksista Helsingin ja Vantaan alueilla. Olemme tutkineet sitä, miten maahanmuuttajataustaiset kaupunkilaiset pääkaupunkiseudulla kokevat kaupunkitilat ja millaisia tunnemerkityksiä tiloihin ja paikkoihin liittyy. Videoitujen kävelyhaastattelujen tavoite on ollut yhtäältä saada paikkoja käsittelevän puheen rinnalle visuaalista materiaalia ja toisaalta tallentaa kuvamateriaalia kaupungista arkistoitavaksi. Videoaineisto tarjoaa myös kiinnostavaa materiaalia paikkoja koskevan haastattelupuheen ja havainnointiaineiston rinnalle: paikkojen suhde kerrontaan avautuu yksityiskohtaisemmin ja mahdollistaa analyysin, jossa paikan merkityksiä voi eritellä ja inmetellä toisin kuin havainnointi- ja haastatteluaineiston avulla. Etnografiassa ajateltiin aikaisemmin videomateriaalin välittävän kulttuureista objektiivista tietoa, mutta 1990-luvun loppupuolella videoitua materiaalia alettiin tarkastella toisella tavalla. Videota ei enää käytetty vain tallentamisen vuoksi, vaan sitä alettiin lähestyä välineenä, jonka avulla tuotetaan etnografista tietoa. (Pink 2013, 96.) Videomateriaalin käyttöä etnografiassa alettiin jaotella sen mukaan, pyrittiinkö analyyseissä objektiiviseen kuvaukseen vai suhtauduttiinko videomateriaaliin luovemmin. Kun etnografisella videolla tähdättiin asioiden objektiiviseen esittämiseen, ei materiaalia saanut leikata tai muutoin muokata. Osa tutkijoista alkoi 1990-luvulla käyttää enemmän luovuutta videoiden teossa. (Pink 2013, 97-98.) Etnografi 
Sarah Pink $(2013,98)$ on kritisoinut käsitystä, jossa videomateriaalia tarkastellaan (jotenkin) yksiselitteisen objektiivisena materiaalina ja tieteellisenä dokumenttina. Hän painottaa, että videoaineisto on ennen kaikkea representaatio todellisuudesta. Videointi muokkaa ihmisten toimintaa: se vaikuttaa siihen, millaista tietoa he tutkimusaiheesta tuottavat. Kuten mikä tahansa etnografinen representaatio, myös videomateriaali on konstruktio. Etnografinen tieto ei välttämättä myöskään ole olemassa havainnoitavina faktoina, vaan se koostuu kenttäkokemuksista ja vuorovaikutuksesta. Videomateriaalin käyttämisessä tulisikin kiinnittää erityistä huomiota siihen, miten se osallistuu tiedon tuottamiseen, ja millä tavoin tutkimuksen aihetta koskevat käsitykset ja ymmärrys rakentuvat kenttätyön aikana tapahtuvassa vuorovaikutuksessa. Videomateriaalien hyödyntäminen tutkimuksessa ei merkitse sitä, että niiden nähtäisiin realismin mukaisesti edustavan objektiivista kuvaa todellisuudesta, vaan painotus on siirtynyt näkemykseen, jossa videon tuottamaa käsitystä muokkaavat videon tekijät ja sen katsojat. (Pink 2013, 116; ks. myös esim. Gordon ym. 2017.) Vaikka objektiivisen tallentamisen pyrkimyksistä on luovuttu, on videoinnin taustalla silti herkästi ajatus siitä, että video välittää tietoa esimerkiksi paikoista sellaisenaan. On kuitenkin olennaista pohtia, mikä jää kuvatun ulkopuolelle tai kuinka rajaukset haastattelupuheessa ja kuvassa tuottavat paikan aivan tietynlaisena muokaten siitä yhdenlaisen käsityksen: videokameraa ja sille tallentunutta maisemaa voidaan lähestyä toimijuuden näkökulmasta. Videokuvallisen materiaalin analyysissa tiedon paikantumiseen ja rakentumiseen sekä lähdekritiikkiin liittyvä pohdinta on olennaista tiedon arvioinnin kannalta. Kuvaus, valitut reitit, kysymykset ja vastaukset ovat osittaisia ja kontekstisidonnaisia, kuten etnografinen tutkimus yleensäkin.

Paikan rakentuminen videoidussa kävelyhaastattelussa avaa näkymiä sen tarkasteluun, miten paikan merkitykset muotoutuvat performatiivisesti materiaalis-diskursiivisessa toiminnassa: haastattelijoiden, haastateltavan sekä paikkojen ja reittien ja niitä tallentavan videokameran toisiinsa kietoutuneessa vuorovaikutuksessa. Paikka rakentuu kävelyssä ja liikkeessä: sen muodostuminen on sidoksissa ruumiillisuuteen ja ruumiilliseen kokemiseen (Pink 2007, 245, 249; Aula 2018; Korjonen-Kuusipuro ja Kuusisto-Arponen 2017). Kävely on siirtymisiä, ja nämä siirtymät muodostavat reittejä, jotka olennaisesti osallistuvat paikkojen muokkaamiseen (Lee ja Ingold 2006, 68). Siirtymisten lisäksi reitit sisältävät myös perillä oloa, pysähdyksiä. Ajattelen, että pysähdyksiin tiivistyy jotakin sellaista, mikä on tärkeää paikkakokemuksen ymmärtämiseksi. Tarkastelen aineistosta neljää pysähdystä: miten paikka merkityksellistyy näissä pysähdyksissä videoidun kävelyhaastattelun vuorovaikutuksessa, kun vuorovaikutukseen osallistuvat haastattelijat, haastateltava ja maisema videokuvan välittämänä?

Esittelen aluksi kävelyhaastattelua ja videoitua kävelyhaastattelua etnografisen tutkimuksen menetelminä. Tämän jälkeen käsittelen lyhyesti uusmaterialismiin liittyvää feministisen tutkimuksen keskustelua epäinhimillisestä toimijuudesta, koska pohdin myös videokuvan toimijuutta paikan merkitysten muokkaamisessa. Tulkitsen paikkojen merkityksellistämistä performatiivisen teorian kehyksessä, jossa eri toimijat ovat toisiinsa kietoutuneita ja muokkaavat todellisuutta ja paikkoihin kytkeytyviä käsityksiä, muistoja ja merkityksiä. Tämän jälkeen kuvaan aineistoa, johon katsauksen analyysi pohjautuu, ja tulkitsen paikkojen määrittymistä videoitujen kävelyhaastattelujen vuorovaikutuksessa. Analysoin videoilta kohtia, joissa on pysähdytty johonkin paikkaan. Lopuksi pohdin videoidun kävelyhaastattelun erityisyyttä etnografisena menetelmänä. 


\section{Kävelyhaastattelu menetelmänä}

Antropologiseen ja etnografiseen tutkimukseen on kuulunut oletus siitä, että ymmärtääkseen tutkittavien yhteisöjen kulttuurisia käytäntöjä ja merkityksiä tutkijan on pyrittävä sallistumaan kyseisen yhteisön toimintaan ja arkeen. 1990-luvulla ja 2000-luvun taitteessa alettiin korostaa myös aistillista ja ruumiillista kokemusta yhtenä osallistumisen menetelmänä. Käveleminen on nostettu yhdeksi keskeiseksi menetelmäksi, jonka kautta voimme paremmin ymmärtää ihmisten suhdetta sosiaalisiin ja kulttuurisiin ympäristöihinsä.

Tutkittavien kanssa kävelemisellä on etnografiassa pitkät perinteet, mutta erityisenä tutkimusmenetelmänä sitä on alettu systematisoida vasta myöhemmin (Pink 2007; Jokinen ym. 2010; Lee ja Ingold 2006). Nykyisin se on yksi etnografisen tiedon tuottamisen menetelmä, jonka on todettu ilmentävän hyvin paikkoihin kytkeytyviä merkityksiä, tunteita ja käsityksiä. Kävelyhaastattelussa yhdistyvät kävelyn antropologia ja aistimellinen antropologia (Pink 2007, 245). Antropologi Inkeri Aula (2018) on tutkinut "aistielämäkerrallisen kävelyn" keinoin maisemakokemusta ja aistien kautta rakentuvaa suhdetta ympäristöön. Hänen tarkastelutavassaan on uusmaterialistinen ote, jossa kaupunkilaisen kokemusta ja aistittua maisemaa lähestytään dynaamisesti toisiinsa kietoutuneina (Aula 2018, 91).

Kävelyhaastattelu on sidoksissa fenomenologiseen tutkimusperinteeseen: sen kautta yritetään ymmärtää, millaisia kokemuksia ihmisillä paikkoihin liittyy ja miten kokemukset syntyvät. Sosiologi Margarethe Kusenbach (2003) on kehittänyt kävelyhaastattelun menetelmää kanssakulkemiseksi tai kanssakävelyksi (go-along) tutkiessaan arkisia paikkasuhteita. Kusenbach huomioi fenomenologisen reduktionismin ideaalisuuden: tutkittavan kulttuurin ja yhteisön jäsenten kokemuksellista tietoa ja kokemusta ei voida täydellisesti saavuttaa, mutta kokemuksia voidaan kuitenkin fenomenologisesti tutkia esimerkiksi kanssakulkemisen menetelmällä. Kanssakulkeminen voi avata sekä sitä, miten paikka konstituoi kokemusta, että sitä, miten poikkeuksellisia ja arjesta irtaantuvia kokemuksia paikkaan liittyy. (Kusenbach 2003, 457-458; Pink 2007, 246; Jokinen ym. 2010, 257.) Kanssakulkemisen idea on, että tutkijat kulkevat tutkittavien mukana heidän valitsemillaan ja arkisilla reiteillä kysellen, kuunnellen ja havainnoiden sekä tarkastellen heidän kokemuksiaan ja käytäntöjään, kun he kulkiessaan ovat vuorovaikutuksessa fyysisen ja sosiaalisen ympäristön kanssa. Menetelmä valottaa paikan asemaa arkisessa eletyssä kokemuksessa. (Kusenbach 2003, 463; ks. myös Lee ja Ingold 2006, 83.) Menetelmän avulla voidaan saada tietoa siitä, miten ympäristöä havainnoidaan, miten se näyttäytyy, miten tiloja käytetään, kuinka elämäkerrallinen tieto jäsentyy kävelyn aikana ja suhteessa paikkoihin sekä millainen on kyseisen paikan sosiaalinen arkkitehtuuri ja sosiaalinen maailma rajoineen (Kusenbach 2003, 456). Kävelyn kautta tiloista ja paikoista voi paljastua uudella tavalla ihmisille tärkeitä elementtejä ja paikkoihin liitettävien merkitysten kontekstisidonnaisuus ja varioivuus voivat tulla esiin (esim. Suopajärvi 2014; Pink 2007; 2009; 2011). Kristiina Korjonen-Kuusipuro ja Anna-Kaisa Kuusisto-Arponen $(2017,13)$ toteavat, että paikkoihin ja ympäristöön liitettävät yhteisölliset ja subjektiiviset merkitykset ja kokemukset avautuvat yksityiskohtaisemmin silloin, kun kehollisuutta, muistelua ja materiaalisia elementtejä tarkastellaan rinnakkain ja tilannesidonnaisesti (ks. myös Aula 2018). Kävelyhaastattelussa muotoutuvan kerronnan paikkoja koskevat merkitykset saavat poiketa siitä, miten kaupunkitilaa tavallisesti arvotetaan (Aula 2018, 90). Kävelyä on hyödynnetty myös kaupunkisuunnittelun välineenä; menetelmän avulla on voitu saada tietoa esimerkiksi alueen turvallisuudesta tai käveltävyydestä (Jokinen ym. 2010, 258). 
Antropologi Tim Ingoldin $(2004,331)$ mukaan toimintaa tutkittaessa tulisi liikkumisen olla kognition sijaan tutkimuksen lähtökohta. Näkemisen lisäksi ympäristö koetaan myös muilla aisteilla, ja kokemuksen muodostuminen on siis ensisijaisesti ruumiillista. Kävely on tapa havaita ja olla vuorovaikutuksessa ympäristöjemme kanssa, ja kävelyn avulla paikoista voidaan saavuttaa monipuolisempaa erilaisiin aistikokemuksiin kiinnittyvää tietoa. (Pink 2007, 244-245; 2009; Ingold 2004; Lee ja Ingold 2006; Korjonen-Kuusipuro ja Kuusisto-Arponen 2017; Aula 2018.)

Tutkittavan kulttuurin merkitysten ymmärtäminen on sidoksissa paitsi puheeseen ja diskursseihin, myös ruumiilliseen toimintaan, aisteihin, arkipäivän reitteihin ja niissä rakentuvien paikkojen ja ympäristön merkityksenantoprosesseihin (Lee ja Ingold 2006, 83; Aula 2018; Korjonen ja Kuusipuro 2017). Sarah Pink (esim. 2007; 2013) on analysoinut videoituja kävelyhaastatteluja etnografisen tiedon tuottamisessa. Pink korostaa (2007, 245-249) paikan rakentuvan kävelyssä ja liikkeessä. ${ }^{1}$ Pinkin menetelmällisen pohdinnan lähtökohtana on muun muassa de Certeaun (1984) ymmärrys paikan muotoutumisessa liikkeessä, mutta hän on kehittänyt menetelmää tukeutuen filosofi Edward Caseyn ajatuksiin. Caseyn mukaan paikat muotoutuvat seuraavissa rakenteissa:1) paikka on kietoutunut ruumiillisuuteen ja siis paikan ruumiilliseen kokemiseen; ) paikkaan liittyy kokoavaa valtaa: se kokoaa ihmisiä ja asioita, tilaa ja aikaa. (Pink 2007, 245-249.)

Paikkaan kietoutuvien kokemusten tutkimiseen ja tavoittamiseen voi videoitu kävelyhaastattelu tarjota toimivan väylän. Pinkin mukaan tutkija voi videon kautta aada kokonaisvaltaisemman käsityksen ja ymmärryksen paikkojen merkityksestä tutkittaville analysoidessaan esimerkiksi videolle tallentunutta vuorovaikutusta. Toiseksi videoitu kävelyhaastattelu muodostuu itsessään paikkaa koskevaksi kulttuurisia jäsennyksiä ja merkityksiä ilmentäväksi ja tuottavaksi esitykseksi. Videoitu kävelyhaastattelu on prosessi, joka luo tilan, jossa ihmiset, asiat ja aistimelliset kokemukset yhdistyvät. (Pink 2007, 245, 248.)

Pink on korostanut aistien merkitystä paikkaa koskevien tulkintojen muodostamisessa. Paikan rakentuminen liikkeessä tuo esiin, miten kokeva ruumis on keskeinen toimija paikan tuottamisessa. Paikka muovautuu suhteessa näkemiseen, kuulemiseen, haistamiseen ja koskemiseen. Samalla ympäristö rakentuu jalanjälkiemme, hengittämisen ja äänen tuottamisen kautta. Paikka muodostuu monista asioista: aisteista, tunteista, sosiaalisista kohtaamisista ja niin edelleen. Reiteissä paikoista tulee tapahtuma, jossa yhdistyvät edellä mainitut elementit. Reittien voi siis nähdä luovan paikkoja. (Lee ja Ingold 2006, 68; Pink 2007, 245, 248.)

\section{Uusmaterialismi ja liikkuvan kuvan toimijuus}

1990-luvun alkupuolella feministisessä teoriassa alettiin lisääntyvästi pohtia biologisen ja luonnon toimijuutta. Tuolloin Donna Haraway totesi, että on mahdotonta osoittaa kohtaa, jossa luonto päättyy ja kulttuuri alkaa. Ne tulisi hahmottaa toisiinsa kietoutuneina, joita molempia luonnehtii toimijuus. Harawayn mukaan (1992, 297; ks. myös 1991) luontoa ei ole ilman sen diskursiivista rakentumista, mutta luonnon tekijöinä ovat muutkin kuin ihmiset. Hänen mukaansa luonto samoin kuin muut tutkittavat objektit eivät ole löytämistään odottavia olioita, vaan ne osallistuvat siihen, mitä ja miten me ne näemme ja siten siihen, minkälaista tietoa tuotamme. (Haraway 1991, 199-201; 151-152, 177; 1992; 1989; ks. myös

1 Myös Tiina Suopajärvi (2014) on analysoinut ikääntyneiden paikkakokemuksia nimenomaan tästä näkökulmasta. 
Hobson 2007; Rojola 2000, 156.) Materiaalisen ja diskursiivisen vastakohtaisuutta on lisääntyvästi purettu painottamalla muunkin ei-inhimilliseksi mielletyn, kuten teknologian, toimijuutta. Ei-inhimillisten elementtien toimijuuden analyysi on jatkunut keskusteluissa uusmaterialismista.

Uusmaterialismissa on tiivistetysti kyse sen analysoimisesta, millaista valtaa materiaalisuudella ja materialla on, miten ne tuottavat asioita ja osallistuvat ilmiöiden muokkaamiseen rinnakkain diskursiivisten prosessien kanssa. Materia ei ole vain passiivista ainesta tai massaa, jota tulkitaan ja merkityksellistetään, vaan materialla voidaan ajatella olevan toimijuus: se muokkaa merkityksellistämistä ja vaikuttaa diskursiiviseen. Diskursiivinen ja materiaalinen ovat lähtemättömästi toisiinsa kietoutuneita. (Ks. Hongisto 2015, 11; ks. myös Irni 2013.)

Uusmaterialistia kysymyksenasetteluja käsitellyt Karen Barad $(1998 ; 2003)$ on kehittänyt toimijuusrealismin teorian (agential realism), jonka ytimessä on ajatus toinen toisiaan muokkaavista toimijuuksista (Barad 2003, 815). Baradille materia on tekemistä, joka koostuu materiaalisen ja diskursiivisen toimijuuden limittymisestä toisiinsa (mts. 825-826). Toimijuus ei ole ominaisuus, jonka voi omistaa, koska objektit tai subjektit eli toimijat eivät ole olemassa sinällään ennen tekemistä. Toimijuus ei ole staattista, vaan se muokkautuu aina relationaalisesti. (Barad 2003, 827; 2007, 214; ks. myös Hobson 2007, 29.) Baradin näkemykset ovat kiinnostavia pohdittaessa sitä, miten etnografinen tieto rakentuu videoidussa kävelyhaastattelussa. Haastateltava, haastattelijat kameroineen ja kävelyreittien videolla näkyvät maisemat ovat vuorovaikutuksessa toisiinsa. Käsitys paikasta ja siihen liittyvät tunteet ja merkitykset rakentuvat tässä vuorovaikutuksessa. Kohde ja havaitsijat eivät ole erillisiä ilmiön muodostamisessa, vaan ne vaikuttavat toisiinsa ja muokkaavat toisiaan. Baradin teorian avulla haastattelun videomateriaalin voi ymmärtää elementtinä, joka aktiivisesti tuottaa paikoista yhdenlaista tulkintaa ja joka on kietoutunut tilanteessa rakentuvaan vuorovaikutukseen.

Ilona Hongisto $(2015,12)$ on analysoinut uusmaterialismin kehyksessä dokumenttielokuvia todellisuutta tulkitsevina ja muokkaavina. Hänen mukaansa dokumenttielokuva ei ole vain kuvaus jostakin, vaan se itse luo todellisuutta ja on osa sitä materiaalista todellisuutta, jota se kuvaa. Uusmaterialistisen käsityksen mukaisesti dokumenttielokuvat eivät vain luo ja rakenna merkityksiä, vaan ne osallistuvat niihin materiaalisiin prosesseihin, joissa todellisuus rakentuu. Vaikka dokumenttielokuva selvästi eroaa kävelyhaastattelun aikana kuvatusta videosta, niissä on myös samoja elementtejä. Dokumenttielokuvat ovat käsikirjoitettuja, mutta sama koskee myös kävelyhaastatteluja. Niitä edeltää tutkimuksen suunnittelu, tutkimuskysymysten muotoilu, haastattelukysymysten pohtiminen, haastateltavien hankkiminen, heidän informointinsa, valmistelu ja niin edelleen. Haastateltavien valitsemat reitit ja kävelyhaastattelun kulku eivät siis tapahdu tyhjiössä, vaan ne ovat yksi mahdollisuus, valinta, tulkinta. Haastattelutilanteessa haastateltava ei kerro pelkästään omasta kokemuksestaan, vaan hän rakentaa yhden mahdollisen kuvan paikoista ja paikkasuhteestaan suhteuttaen sitä ainakin kahteen seikkaan: 1) mitä hän oletti haastateltavan haluavan kysymysten ja muun vuorovaikutteisen toiminnan perusteella kuulla ja 2) miten kerrottu suhteutuu laajempiin sosiaalisiin ja kulttuurisiin käsityksiin kyseisestä paikasta tai vaikka kotiseuturakkaudesta. Haastattelut eivät kerro "puhtaasti" kokemuksista, vaan ne ovat kulttuurisesti ja tilanteisesti muokkaantunutta vuorovaikutteista kerrontaa. (Oinas 2004, 220.) Dokumenttielokuvan ja kävelyhaastattelun kevyt rinnastaminen avaa mahdollisuuden pohtia kävelyn aikana dokumentoidun reitin osuutta todellisuuden materiaalis-diskursiivisessa tuottamisessa. 


\section{Kävelyhaastattelut aineistona}

Ennen analyysia kuvaan lyhyesti, millaiseen aineistoon analyysi perustuu. Haastattelut ovat Helsingin yliopiston kansatieteen kenttätyökurssilaisten tekemiä. Kurssin aihepiirinä olivat tutkimushankkeemme Jaettu kaupunki teemat. Haastattelut on toteutettu keväällä 2018, ja ne sijoittuvat Kamppiin (erityisesti Kampin kauppakeskukseen) ja Kontulaan. En siis ole ollut itse mukana muodostamassa aineistoa ja haastattelutilanteessa läsnä, jolloin videolle tallentunut vuorovaikutus avautuu minulle toisenlaisesta näkökulmasta kuin jos itse olisin ollut paikalla.

Kävelyhaastatteluja tehtiin yhteensä neljä, kummassakin kohteessa kaksi. Haastattelut tehtiin pareittain eli haastattelijoita oli kaksi, ja kummassakin paikassa toimi yksi pari. Kussakin haastattelussa opiskelijat jakaantuivat siten, että yksi keskittyi kuvaamiseen ja toinen haastattelemiseen, vaikka roolit myös limittyivät. Kontulassa haastateltiin kahta keski-ikäistä naista ja Kampissa alle 20-vuotiaita nuoria miehiä. Kontulaan sijoittuvissa haastatteluissa haastateltavana oli molemmissa haastatteluissa yksi henkilö, kun Kampissa nuoria osallistui enemmän. Kampin haastatteluissa toiseen haastatteluun osallistui aluksi kaksi nuorta, mutta kolmas tuli mukaan kesken haastattelun. Toisessa haastattelussa haastateltavina oli kaksi kaverusta.

Kävelyhaastattelut eroavat sen mukaan, kummassa kohteessa ne on tehty. Kampin haastatteluissa haastateltavat kertovat tiiviin informatiivisesti paikoista, mutta keskustelevat myös esimerkiksi vartijoihin liittämistään ristiriitaisista tunteista. Kontulaan sijoittuvissa haastatteluissa käsitellään enemmän muitakin asioita ja haastateltavien elämänhistoriaa. Kontulaan sijoittuvat kävelyhaastattelut kestävät noin tunnin. Ne ovat tunnelmaltaan rauhallisia: ihmisiä tulee vastaan harvemmin ja videoille on tallentunut paljon kohtauksia, joissa ei näy muita ihmisiä. Kampin haastattelut kestävät 10-20 minuuttia. Niiden tempo on nopea, ja jatkuva ihmisten ja liikkeiden virta pulppuaa ympärillä. Haastattelujen kestojen vaihtelua voi selittää paikkojen erilaisilla luonteilla ja sillä, että haastateltavilla oli paikkoihin erilainen suhde: Kontulan haastateltavat kulkivat kotiseuduilla, kun Kamppi on ostoskeskus, tietynlainen läpikulkupaikka ja nuorille yhdenlainen nuorisotalo. Kamppi ei kiireisyydessään ja hälinässään välttämättä houkuttele rauhallisempaan pohdintaan. Kontulan hiljaisemmat maisemat taas luovat toisenlaisen tilan kulkea ja kertoa.

Kontulaan sijoittuvien kävelyhaastattelujen reitit ovat paikoitellen samoja. Ensimmäinen haastattelu kulkee Kontulan ostoskeskuksesta kirkon suuntaan, sieltä urheilukentälle ja takaisin päin toiselle puistoalueelle vanhustenkeskuksen suuntaan, vanhustenkeskuksesta kuljetaan ostoskeskukseen omakotitaloalueen kautta. Toinen haastattelu kulkee samoilla suunnilla lähtien ostoskeskuksesta ja myös päättyen sinne, mutta tässä haastattelussa ei kuljeta kirkon seutuvilla siten kuin ensimmäisessä. Molemmissa haastateltavat esittelevät oikoteitä parkkipaikkojen läpi, mikä yksityiskohtana tuo esiin sen, miten paikat saavat merkityksiä kävelyssä ja käyttötarkoituksissa, joihin kyseisiä paikkoja ei varsinaisesti ole suunniteltu. Jos paikka rakentuu reiteissä, on mielenkiintoista, miten samanlaiseksi paikaksi Kontula tässä suhteessa näissä videoiduissa haastatteluissa määrittyy: sen rajat ja oleelliset kohdat näyttäytyvät yhteneväisinä.

Kampin haastattelut sijoittuvat kauppakeskukseen ja sen ympäristöön. Ensimmäisen haastattelun reitti lähtee Kampin kauppakeskuksen sisältä katutasolta, kulkee kauppakeskuksen 
pääoville, ja sieltä nuorille suunnattuun Walkers-kahvilaan Narinkkatorin laidalle, josta kuljetaan ostoskeskus Forumiin. Forumista tullaan sisäkautta takaisin Kamppiin. Toinen haastattelu toteutetaan ostoskeskuksen tiloissa. Lähtö on ostoskeskuksen ensimmäisen kerroksen jäätelöbaarin edestä, josta kuljetaan nopeasti kerroksista toisiin. Haastattelu päättyy jonkin kerroksen rauhallisempaan nurkkaukseen, jossa haastattelija kysyy haastateltavilta viimeiset kysymykset.

\section{Pysähdyttävät paikat}

Videoilla pysähtymisiä on erityisesti silloin, kun haastateltava haluaa kertoa jostakin asiasta enemmän tai kokee paikan tärkeäksi. Ensimmäisessä nuorten kanssa tehdyssä kävelyhaastattelussa ensimmäinen pysähdys sijoittuu Kampin kauppakeskuksen Narinkkatorin pääovien eteen. Haastattelijat ja haastateltavat kävelevät Kampin kauppakeskuksen katutasolta ulos, pääovien eteen, he pysähtyvät siihen ja heistä toinen alkaa kertoa paikan tärkeydestä. Heille paikka, pääovien edusta, on kohtaamispaikka, jossa tavataan kavereita ja josta voi myös löytää kavereita, jos on heidät hukannut. Haastateltava osoittaa, mistä pylväästä tämä kohtaamispaikka alkaa ja mihin se päättyy. Videokuvassa näkyy haastateltavien lisäksi muita pääovien edessä olevia nuoria ja taustalla liikkuu jatkuvasti inmisiä, jotka ovat tulossa tai lähdössä kauppakeskuksesta. Kun haastateltava on selittänyt paikan merkitystä jonkin aikaa, haastattelija keskeyttää hänet ja ikään kuin aloittaa haastattelun käyden läpi haastatteluun osallistumisen perusasiat. Syntyy vaikutelma, että kävelyhaastattelu on innostanut haastateltavaa kertomaan omasta ympäristöstään, kun haastattelija ei oikein tahdo pysyä haastateltavan vauhdissa. Haastateltava on jo tilanteeseen orientoitunut, kun haastattelija pyrkii rakentamaan tilanteeseen etnografisen tiedon tuottamisen perusstruktuuria.

Kävelyhaastattelussa voi nähdä, miten kaiken läpikulun keskelle nuorille muodostuu oma tila: paikka ei ole heille niinkään Kampin pääsisäänkäynti kuin kohtaamispaikka. Tässä videoidussa vuorovaikutuksessa reitti ja pysähdys tuottavat Kampin ostoskeskusta paikkana, jossa on hahmotettavissa nuorten oma tila. Kusenbachin $(2003,478)$ mukaan kanssakulkeminen voi tarjota erityisen väylän elämäkerrallisen aineiston tutkimiseen: sen avulla voidaan tarkastella jokapäiväisiä tilan kokemuksia ja käytäntöjä, ja menetelmä voi tuoda esiin sen, miten yksilötasolla ympäröivää maailmaa havainnoidaan ja suodatetaan. Kampin kauppakeskukseen sijoittuvat nuorten kanssa tehdyt kävelyt tuovat esiin paikan kiireisyyden ja hälinän, jotka saattoivat vaikuttaa haastattelun pituuteen ja rytmiin, mutta eivät estä nuoria hahmottamasta paikkaa omana, jäsentyneenä, rauhallisena tilana, johon on tultu tapaamaan kavereita. Arjen kokemusten ja käytäntöjen perustava kategoria on paikka. Etnografisen tiedon tuottamisen näkökulmasta videoidun kävelyhaastattelun menetelmä avaa Kampin kauppakeskukseen liittyviä merkityksiä moninaisemmin ja moniaistillisemmin kuin jos paikkaa käsiteltäisiin ainoastaan haastattelupuheessa. Haastattelijat pääsevät paikan keskelle ja tunnelma tallentuu videolle, jolloin myös jälkikäteen kentältä poistuttua tuon ilmapiirin voi toisella tavalla muistaa ja siihen on mahdollista palata.

Toinen kiinnostava pysähdys sijoittuu Kontulaan. Haastattelun alkupuolella haastattelijat kameroineen ja haastateltava ohittavat Kontulan kirkon, jatkavat puistomaista kävelytietä ja saapuvat urheilukentälle. Aurinko paistaa, valonsäteet osuvat urheilukentän maahan ja laitteisiin. Haastateltava kertoo, miten pitää paikan estetiikasta, sillä urheilukentällä on paljon värejä. Videolle tallentuneessa kuvassa voi nähdä maassa olevan neljää eri väriä, varsinaiset kuntoilulaitteet ovat harmaita. Haastateltavan kommenttiin haastattelija vastaa: 
tulee iloinen olo. Tällaisessa pysähdyksessä paikan merkitys rakentuu erittäin myönteiseksi: kuvassa korostuu auringonvalossa ja keväthangessa kylpevä kenttä, taivas on pilvetön kiillottaen esiin urheilukentän värikkään maan. Sekä haastateltava että haastattelija painottavat kenttää hyviä aistimuksia tuottavana julkisena kaupunkitilana: haastateltava kehuu sen estetiikkaa, minkä haastattelija kääntää ilon tuntemiseksi. Paikka asettuu näin ristiriitaan videon alussa esitetyn Kontulan ostoskeskuksen ja myöhemmin videolla esiintyvän puheen kanssa, jossa käsitellään alueen sosiaalisia ongelmia. Tässä kävelyssä, tällä reitillä ja tässä pysähdyksessä Kontulaan liitetyt kielteiset mielikuvat tulevat kumotuksi: haastateltava, haastattelija ja videolle tallentuva kuva yhdessä tuottavat paikan merkityksiä myönteisiksi ja kutsuviksi.

Toisessa Kontulaan sijoittuvassa haastattelussa haastateltava on muuttanut Kontulasta, ja pohjavire aluetta kohtaan on kielteisempi. Kun kävelyhaastattelu lähtee liikkeelle Kontulan ostoskeskuksesta, haastateltava aloittaa kuvailemalla päällimmäisenä Kontulaan liittyvänä tunteenaan olevan turvattomuuden. Yksi kiinnostava pidempi pysähtyminen reitillä sijoittuu vanhustenkeskuksen läheiselle kalliolle. Haastateltava kertoo, miten paikka on ollut tärkeä hänelle ja hänen pojalleen, jonka kanssa haastateltava on siellä viettänyt aikaa pojan ollessa pienempi. Haastattelussa tulee esiin, miten kävelyhaastattelu tuottaa samanaikaisesti tietoa koetusta ja muistetusta maisemasta sekä mahdollistaa moniulotteisemmin kaupunkitilan rakentamattomien tai "unohdettujen" paikkojen merkitysten analysoimisen (ks. Aula 2018, 90). Toinen haastattelija on haastateltavan vierellä, kun videota pitävä haastattelija tulee perässä. Videolle on tallentunut kevättalvinen maisema: kalliota ympäröivät puut ja talot, mutta paikassa on myös avaruutta, mitä tihentää pilvetön, korkea taivas. Muita kulkijoita ei näy. Kameraa pitelevä haastattelija on välillä kauempana ja kuvaa panoraamatyyliin ympäröivää maisemaa. Haastattelussa ilmenee, että haastateltavan mukaan kalliolla voi mieltää kaksi vastakkaista maailmaa lähellä toisiaan: ostoskeskuksen levottomuus ja vilinä asettuvat kiinnostavasti kallioiden rauhallisuutta vasten.

Kävelyhaastattelun videolle tallentuneissa kuvissa, haastattelijoiden puheessa ja haastateltavan naisen nostalgisessakin muistelussa paikka rakentuu rauhalliseksi, seesteiseksi, jopa pysähtyneeksi hedelmällisellä tavalla: on tilaa ja aikaa palata muistelemaan menneitä tapahtumia ja omaan lapseen liittyviä muistoja. Kanssakulkeminen tarjoaa väylän tarkastella sitä, miten arkiset kokemukset avautuvat ajassa ja tilassa ja kuinka yksilöt muodostavat erilaisia arjen identiteettejään sekä suhdettaan menneeseen. Arkisen paikkakokemuksen kautta haastateltava alkaa käsitellä elämänhistoriaan liittyviä asioita: paikkaan menemisen ja siellä olemisen kautta irtaannutaan tässä ja nyt -kokemuksesta ja siirrytään muistelemaan. (Ks. Kusenbach 2003, 478.) Aistietnografinen tarkastelu auttaa huomioimaan, kuinka kehon kautta paikkaan liittyvät merkitykset voivat rakentua. Korjonen-Kuusipuro ja Kuusisto-Arponen $(2017,13)$ tuovat esiin, miten paikkojen merkitykset voivat kehollisen kokemisen kautta muotoutua uudella tavalla tai ylipäätään tulla taas muistetuiksi. Paikan tarkastelu kävelyn ja muiden aistien kautta voi kertoa paikan merkityksistä enemmän kuin haastattelupuhe.

Pysähtyminen merkitsee reitin varrelle sijoittuvan paikan erityisyyttä, ja samalla tuota paikkaa rakennetaan reittien ja kävelyn kautta. Kävelyhaastattelu tai kanssakulkeminen ei merkitse, että tutkijana voisi päästä käsiksi tutkittavan kokemusmaailmaan, mutta se kuitenkin tuottaa mahdollisuuden tarkastella tutkittavan kuvaamaa kokemusta moniulotteisemmin, eri aisteja hyödyntäen. Se avaa näköaloja siihen, miten paikka voidaan aistia, kuinka aistimukset paikantuvat, miten aistien kautta tuotetaan paikkaa sekä jäsennetään kaiken 
kaikkiaan paikkaan liittyvää kokemusta (ks. Pink 2007, 243; Aula 2018; Korjonen-Kuusipuro ja Kuusisto-Arponen 2017). Videolla haastateltava ja haastattelija viipyvät kalliolla, on hiljaisia hetkiä, katsotaan ympärille, kauas. Videoituna tällainen kävelyhaastattelun pysähdys tekee tutkijalle mahdolliseksi palata toisella tapaa paikan aistimelliseen kokemiseen ja pohtimaan sen merkityksiä tutkittaville aineellisia ja aineettomia näkökulmia yhdistellen.

Viimeiseksi kiinnitän huomiota kyseisen haastattelun lopetukseen. Haastattelijat ja haastateltava saapuvat Kontulan ostoskeskuksen ylätasanteelle. Videokuvassa näkyvät haastateltava ja haastattelija, taustalla silta ja urheiluhallin rakennus logoineen. Sitten videokameraa käyttävä haastattelija toteaa sulkevansa kameran. Hän perustelee sitä sillä, että ostoskeskuksessa kaikki eivät pidä siitä, että siellä kuvataan. Kun haastattelu alkoi, he kulkivat ostoskeskuksen läpi kamera päällä ja joku ohikulkija sanoi siitä jotain epäselvää. Kameran sulkeminen liittynee tuohon kohtaamiseen. Pohdin, vaikuttiko tähän ratkaisuun se, että haastateltava suhtautui varautuneemmin Kontulaan ja toi esiin alueen ongelmia ja turvattomuutta. Kun paikan rakentumista tarkastelee myös videolle tallentuvan maiseman toimijuuden näkökulmasta, on kiinnostavaa, kuinka videokuva tässä tuottaa Kontulan ostoskeskuksen niin arvaamattomana ja pelottavana, että videointi on lopetettava. Toinen haastattelija myöntyy tähän ratkaisuun, mutta haastateltava suhtautuu tähän ehkä lievällä hämmennyksellä. Kun kallioiden päällä paikkaa kuvattiin pitkään ja perusteellisesti, ostoskeskuksen "vastakkainen maailma" suljetaan kokonaan paikan muodostamisen, neuvottelun ja jäsentämisen ulkopuolelle. Jos videokuvaa lähestytään toimijana, joka rakentaa kohteesta tietynlaista mielikuvaa ja luo paikkaa (ks. Hongisto 2015; Barad 2007), Kontulan ostoskeskus määrittyy erittäin kielteiseksi. Se onkin nyt jotain sellaista, jota ei voi tallentaa. Tämä pysähdys näyttää paikan voiman: Kontulan ostoskeskukseen tiivistyy paljon alueen ongelmallisesta maineesta. Se on keskittymä, jossa esiintyy häiriökäyttäytymistä ja jossa sosiaaliset ongelmat ovat esillä. Tässä kävelyssä videolle tallentuneena maisemana Kontulan ostoskeskus on juuri niin huono maineeltaan kuin millaisena sitä usein, ja tässäkin haastattelussa, kuvataan (Ojanen 2018; Kemppainen 2017). Tätä alleviivaa se, että kameran sulkemishetkellä kuvassa ei näy haastattelun ulkopuolisia ja tila on rauhallinen. Aula $(2018,80)$ tuo Anthony de Melloon viitaten esiin, että näemme maailman sellaisena kuin itse olemme, emme sellaisena kuin se on. Paikat merkityksineen rakentuvat eri toimijoiden toisiinsa kietoutuvassa merkityksenannossa kävellessä, reiteissä ja pysähdyksissä. Tämä pysähdys päätti haastattelun ja suuntasi paikkaa koskevaa määrittelyä osoittaen ostoskeskuksen seudun ongelmallisen luonteen osana Kontulan paikkaa. Pysähtyminen voi näin avata erityisellä tavalla paikkaan liittyviä merkityksiä ja olla kiinnostava etnografisen tiedon tuottamisen kannalta.

\section{Videoitu kävelyhaastattelu kokemuksellisen tiedon tuottamisessa}

Videolle tallentunut maisema ja haastattelutilanne ovat yksi tekijä paikoista muotoutuvien merkitysten määrittämisessä. Videokuva asettuu myös vuorovaikutukseen haastattelijan ja haastateltavien puheen kanssa. Kyseessä on analyysivaiheen merkityksenanto: videokuva on jälkikäteen analysoitu dokumentti, joka tallentaa vain osan maisemasta, kun video yhdessä maiseman kanssa on ollut osallinen vuorovaikutustilanteessa. Videokuva muokkaa todellisuutta ja alleviivaa paikkojen rajoja. Kun halutaan tutkia paikkaan ja tiloihin liittyviä merkityksiä, videoitu kävelyhaastattelu tarjoaa rajoituksista huolimatta toimivan menetelmän ymmärtää paikkoihin liittyviä käsityksiä ja tunteita. Kävely reitteineen rakentaa ja jäsentää paikkaa, jolloin reittien videointi avaa uusia näkökulmia paikan rakentumisen prosessiin. Olen tässä katsauksessa pohtinut sitä, miten paikkaan liittyviä merkityksiä voi ymmärtää 
videoidun kävelyhaastattelun kautta. Lähtökohtani oli pohtia eri toimijoiden, haastattelijan, haastateltavan ja ei-inhimillisen toimijan eli videolle tallentuneen maiseman vuorovaikutusta paikkaan liittyvien merkitysten muodostamisessa etnografisen tiedon kannalta.

Kävelyhaastattelu ja videoitu kävelyhaastattelu ovat metodisesti lähellä toisiaan. Kävelyhaastattelu voi usein riittää, mutta videon käyttäminen saattaa olla perusteltua esimerkiksi muistin tukena tai tutkimuskysymysten vuoksi (Pink 2007, 250). Kusenbach $(2003,477-478)$ on todennut, että tällaisia menetelmiä voi käyttää muiden etnografisten menetelmien, kuten havainnoinnin, ohella, mutta kaikkien ilmiöiden tutkimiseen menetelmä ei sovellu. Esimerkiksi jos toiminta ei edellytä vuorovaikutusta ympäristön kanssa, ei kävelyhaastattelu tai kanssakulkeminen välttämättä ole toimiva menetelmä ilmiön tutkimiseksi.

Kanssakulkeminen mahdollistaa tutkijoille toisenlaisen pääsyn tutkittavien arkeen, siihen miten arjen kokemukset avautuvat ajassa ja tilassa ja kuinka yksilöt muodostavat arjen erilaisia identiteettejään. Tämä erottaa menetelmän esimerkiksi perinteisestä haastattelusta. Sen avulla voi havaita, miten esimerkiksi arkisten, jokapäiväisten paikkakokemusten kautta voidaan käsitellä elämänhistoriaan liittyviä asioita: tavallisen kokemuksen kautta voidaan päästä tässä ja nyt -kokemuksen yläpuolelle. Johonkin tilanteeseen liittyvä toiminta jossakin paikassa voi avata kokemuksia menneeseen ja auttaa ymmärtämään kulttuurisia jäsennyksiä. Menetelmä osoittaa, että maailmasuhteemme on refleksiivinen. (Kusenbach 2003, 478.)

Kävelyhaastattelu voi mahdollistaa moniulotteisemman ja moniaistisemman etnografisen ymmärryksen ihmisten paikkasuhteista, paikkoihin liittyvistä merkityksistä ja paikan rakentumisesta. Kun kulttuurisia ilmiöitä tai identiteettikertomuksia tutkitaan tällä tavoin liikkeessä, osana arjen ympäristöä, voidaan analysoida, miten merkitykset rakentuvat kehollisuuden ja eri aistien kautta sekä millaisin mekanismein arkinen kokeminen yhdistyy käsityksiin menneestä, nykyisestä ja tulevasta. Paikka on muoto, joka kokoaa asioita yhteen (Pink 2007, 245, 248).

Näen videoidun kävelyhaastattelun edun olevan yhtäältä siinä, että sen avulla tarkka vuorovaikutuksen ja paikkasuhteen analyysi on mahdollista, ja toisaalta se toimii tutkijan muistin ja aistimuksiin perustuvien huomioiden tukena. Videoitu kävelyhaastattelu mahdollistaa yksityiskohtaisemman vuorovaikutuksen analyysin sekä erilaisten eleiden, ilmeiden ja liikkeiden tarkastelun osana paikkojen merkitysten muodostumista. Videon avulla voi olla helpompi palata tutkijana niihin tunteisiin, aistimuksiin, ajatuksiin ja muistoihin, joita haastattelun aikana herää. Videon käyttäminen tarjoaa videolle tallentuneen kuvan analyysin osana paikkasuhteen ja arkisen paikkakokemuksen rakentumisen tutkimusta: mitä kuvataan, millä tavoin, miten rajauksia tehdään, mitä jätetään ulkopuolelle sekä miten kuva ja puhe ovat yhteydessä toisiinsa. Videoitua kävelyhaastattelua voi lähestyä dokumenttielokuvana, jolloin elokuvan voi tulkita osallistuvan todellisuuden luomiseen ja niihin materiaalisiin prosesseihin, joissa todellisuus rakentuu (ks. Hongisto 2015). Materia, videokuva, omaa tässä mielessä toimijuutta ja on yhteen kietoutunut diskursiivisen kanssa. Ne muokkaavat toinen toisiaan (ks. Barad 2003, 815). Haastateltava, haastattelijat kameroineen, kävelyreittien ja pysähdysten videolle tallentuneet maisemat vaikuttavat paikan ja siihen liittyvien merkitysten muodostumiseen. Yhdessä nämä eri näkökulmat voivat olla hedelmällisiä analyysin välineitä. 
Samalla kun kävelyhaastattelu ja videoitu kävelyhaastattelu ovat toimivia etnografisen tiedon tuottamisen menetelmiä, koskevat niitä tavalliset lähdekriittiset pohdinnat. Etnografinen video tuottaa aina historiallisen tekstin, se ei kerro tästä hetkestä, vaan on yksi tulkinta menneestä (Pink 2007, 250). Videoitu kävelyhaastattelu on tulkinta paikasta ja siihen liittyvästä kerronnasta. Haastattelutilanne ohjaa sitä, mitä ja millä tavoin haastateltava paikoista kertoo ja millaisen reitin hän rakentaa, minne hän pysähtyy. Kuten haastattelu tavallisestikin, myös videoitu kävelyhaastattelu on vuorovaikutteista toimintaa, jota ohjaavat erilaiset oletukset ja normit. Se on ennen kaikkea yksi rajattu tulkinta paikasta ja kulkemiseen kytkeytyvästä kerronnasta. Tässä mielessä videoitu kävelyhaastattelu lähenee dokumenttielokuvaa. Dokumenttielokuvan pyrkimys kuvata todellisuutta ei ole passiivista toimintaa, vaan aktiivinen teko, jossa tuotetaan tietynlaista kerrontaa. Dokumentaarinen havainnointi osallistuu kulloisenkin tarinan luomiseen, jota muokkaavat elokuvantekijä, kamera ja kuvattavat henkilöt. Dokumenttielokuva on aina eräänlainen kameroille suunnattu esitys. (Hongisto 2015, 67-68.) Vaikka videon käyttö kävelyhaastattelussa ei täysin rinnastu dokumenttielokuvaan, on kuitenkin selvää, että video muokkaa haastattelutilannetta.

Videoitu kävelyhaastattelu edellyttää tutkijalta erityistä reflektiivisyyttä silloin, kun kävely toteutetaan itselle tutussa paikassa. Minulle sekä Kampin että Kontulan alueet ovat tuttuja, Kontulassa olen myös itse tehnyt kenttätutkimusta. Katsoessani nyt Kontulaan sijoittuvia videohaastatteluita minun oli vaikea saada niihin etäisyyttä: paikat näyttivät tutuilta paikoilta, jotka herättivät itsessä erilaisia muistoja. Arkiseen ympäristöön liitettävien tunteiden ja aistimusten kuvailu ei välttämättä ole helppoa (esim. Aula 2018, 76). Toisella haastattelijoista aktivoituu paikkaan liittyviä muistoja, ja hän tuo esiin, että paikat ovat hänen lapsuudenmaisemiaan, mikä joltain osin ohjasi hänen toimintaansa haastattelutilanteessa ja olisi saattanut vaikeuttaa etnografisen etäisyyden rakentamista. Myös haastateltavan voi olla vaikea eritellä paikkoihin liittyviä ajatuksia ja tunnetiloja: toisessa Kontulaan sijoittuvassa haastattelussa haastateltava toteaa, että on vaikea puhua paikkoihin liittyvistä tunteista, kun niissä viettää aikaa päivittäin. Kävelyhaastattelu edellyttää reflektiivisyyttä kuten muutkin etnografiset menetelmät. Tutkijana etäisyyttä voi löytää paikkaa koskevista teoreettisista jäsennyksistä.

Videoitu kävelyhaastattelu voi tuottaa erityistä paikkoihin sidottua kokemuksellista tietoa, jossa käsitellään paikkojen kautta ja niihin sidoksissa olevaa elämänhistoriaa sekä kulttuurisia ja yhteiskunnallisia jäsennyksiä. Videoidussa kävelyhaastattelussa tämä tieto voi asettua yksityiskohtaisemmin ja moniaistillisemmin analysoitavaksi kuin haastattelussa ja havainnoinnissa. Videoidun kävelyhaastattelun avulla voi analysoida tarkemmin maisemien ja paikkojen rakentumiseen vaikuttavia yhteen kietoutuneita elementtejä: kehollisuutta, puhetta ja materiaalista ympäristöä. Menetelmän käyttäminen ja tarkka analyysi voivat avata etnografiseen tiedon tuottamiseen uusia näkökulmia (ks. esim. Aula 2018). Samalla menetelmä edellyttää etnografiselle tutkimukselle tuttujen lähdekriittisten edellytysten huomioimista ja reflektiivistä arviointia. 


\section{Kirjallisuus}

Aula, Inkeri. 2018. "Aistikävely kaupunkimaisemaan - yhteisen tilan kokemus ja joutomaiden polut. "Elore 25(1): 74-95.

Barad, Karen. 1998. "Getting Real: Technoscientific Practices and the Materialization of Reality." A Journal of Feminist Cultural Studies 10(2):287-128. https://doi.org/10.1086/345321

Barad, Karen. 2003. "Posthumanist Performativity: Toward an Understanding of How Matter comes to Matter." Signs. Journal of Women in Culture and Society 28(3): 801-831. https:// doi.org/10.1215/9780822388128.

Barad, Karen. 2007. Meeting the Universe Halfway. Quantum Physics and the Entanglement of Matter and Meaning. Durham: Duke University Press.

de Certeau, Michel. 1984. The practice of everyday life. Berkeley: University of California Press.

Gordon, Lisi, Charlotte Rees, Jean Ker ja Jennifer Cleland. 2017. "Using video-reflexive ethnography to capture the complexity of leadership enactment in the healthcare workplace." Advances in Health Sciences Education 22(5): 1101-1121. https://doi. org/10.1007/s10459-016-9744-z

Haraway, Donna. 1989. Primate Visions. Gender, Race, and Nature in the World of Modern Science. New York: Routledge.

Haraway, Donna. 1991. Simians, Cyborgs, and Women: The Reinvention of Nature. New York: Routledge.

Haraway, Donna. 1992."The Promises of Monsters: A Regenerative Politics of Inappropriate/d Others." Teoksessa Cultural Studies, toimittaneet Lawrence Grossberg, Cary Nelson ja Paula Treichler, 295-337. New York: Routledge.

Hobson, Pru. 2007. "Beasts and Boundaries: An Introduction to Animals in Sociology, Science and Society. Qualitative Sociology Review 3(1): 23-41.

Hongisto, Ilona. 2015. Soul of the documentary: Framing, expression, ethics. Amsterdam: Amsterdam University Press. https://doi.org/10.1515/9789048525294

Ingold, Tim. 2004. "Culture on the ground." Journal of Material Culture 9(3): 315-340. https:// doi.org/10.1177/1359183504046896

Irni, Sari. 2013. "Kun jälkistrukturalismi kohtaa luonnontieteistä inspiroituneen uusmaterialismin: Herkän luennan harjoitus." Sukupuolentutkimus 26(4): 5-16.

Jokinen, Ari, Eveliina Asikainen ja Kirsi Mäkinen. 2010. "Kävelyhaastattelu tapaustutkimuksen menetelmänä." Sosiologia 47(4): 255-269.

Kemppainen, Teemu. 2017. Disorder and insecurity in a residential context: $A$ study focusing on Finnish suburban housing estates built in the 1960s and 1970s. Helsinki: Helsingin kaupunki.

Korjonen-Kuusipuro, Kristiina ja Anna-Kaisa Kuusisto-Arponen. 2017. "Muistelun monet muodot - kertomus, kehollisuus ja hiljaisuus paikan tietämisen tapoina" Elore 24(1): $1-17$.

Kusenbach, Margarethe. 2003. "Street phenomenology: The go-along as ethnographic research tool." Ethnography 4(3): 455-485. https://doi.org/10.1177/146613810343007

Lee, Jo ja Tim Ingold. 2006. "Fieldwork on Foot: Perceiving, Routing, Socializing." Teoksessa Locating the Field:Space, Place and Context in Anthropology, toimittaneet Simon Coleman ja Peter Collins, 67-85. New York: Berg. 
Oinas, Elina. 2004. "Haastattelu: Kokemuksia, kohtaamisia, kerrontaa."Teoksessa Feministinen tietäminen. Keskustelua metodologiasta, toimittanut Marianne Liljeström, 209-227. Tampere: Vastapaino.

Ojanen, Karoliina. 2018. "Erojen yhdentekevyydestä jokapäiväiseen rasismiin: Monikulttuurisia kohtaamisia Helsingin lähiöissä." Alue ja ympäristö 47(1): 3-16.

Pink, Sarah. 2007. "Walking with video." Visual Studies 22(3): 240-252. https://doi. org/10.1080/14725860701657142

Pink, Sarah. 2009. Doing Sensory Ethnography. Thousand Oaks: Sage. https://doi. org/10.4135/9781446249383

Pink, Sarah. 2011. "From Embodiment to Emplacement. Rethinking Competing Bodies, Senses and Spatialities." Sport, Education and Society 16(3): 343-355. https://doi.org/10. 1080/13573322.2011.565965

Pink, Sarah. 2013. Doing Visual Ethnography. London: Sage.

Rojola, Sanna. 2000. "Donna Haraway - mieluummin kyborgi kuin jumalatar." Teoksessa Feministejä - aikamme ajattelijoita, toimittaneet Anneli Anttonen, Kirsti Lempiäinen ja Marianne Liljeström, 137-160. Tampere: Vastapaino.

Suopajärvi, Tiina. 2014. "Kävelyssä rakentuva paikka: Oulun kaupunkikeskusta seniorikaupunkilaisten sosiomateriaalisena ympäristönä." Sosiologia 51(4): 332-346.

FT, VTM Karoliina Ojanen on toiminut kansatieteen ja folkloristiikan tutkijana Helsingin yliopistossa. 